\title{
Ecological assessment of the lowland relit forest "Bosco delle Sorti della Partecipanza" in Trino (North-Western Italy), applying Diptera Syrphidae as bioindicators
}

\author{
U. Maritano \\ Indipendent researcher, Condove, Italy
}

\begin{abstract}
The survey has been realized in the lowland relict forest Bosco delle Sorti della Partecipanza, a site situated in Trino (Piedmont, North-Western Italy), to assess the ecological conservation level of forest habitats using the Syrph the Net methodology. 67 species were recorded, using three Malaise traps, seven Emergence traps and several Net transect in the year 2020. Among these species, 6 are reported for the first time in Piedmont region, 19 are considered decreasing at European level and 2 are threatened in Europe. Forest habitats under scrutiny in the study area are oak-hornbeam mesophilic woodland and alluvial alder lowland. The data analysis allowed to compare observed with expected syrphids for each habitat. At the ecosystem level, the ecological integrity of the for-
\end{abstract}

Correspondence: Umberto Maritano, Condove (TO), Italy.

E-mail: umberto.maritano@gmail.com

Key words: Syrph the Net, bioindicator, hoverflies, pollinators, Piedmont, ecological integrity, Myolepta obscura

Acknowledgements: Special thanks to Daniele Sommaggio for helping me in the identification of some critical species. I am grateful to Lorenzo Bianco for precious suggestions which he made in the first draft on the manuscript. I sincerely thank the anonymous reviewer for useful comments. I would like to thank "Ente di gestione delle aree protette del Po vercellese-alessandrino" to giving me permission to sample in "Bosco delle Sorti della Partecipanza" in Trino.

Conflict of interest: The author declares no potential conflict of interest.

Funding: None.

Received for publication: 16 January 2021

Revision received: 11 March 2021.

Accepted for publication: 19 April 2021.

${ }^{\circ}$ Copyright: the Author(s), 2021

Licensee PAGEPress, Italy

Journal of Entomological and Acarological Research 2021; 53:9617 doi:10.4081/jear.2021.9617

This article is distributed under the terms of the Creative Commons Attribution Noncommercial License (by-nc 4.0) which permits any noncommercial use, distribution, and reproduction in any medium, provided the original author(s) and source are credited. est is moderately negative but the alluvial alder forest macrohabitat can be considered good and overall saproxylic and saprophagous species are particularly well-preserved. The presence of a high number of rare or decreasing species makes Trino wood an important source of biodiversity in Po Plain.

\section{Introduction}

Forest ecosystems represent an invaluable source of biodiversity and they are precious elements for the insect conservation (Ulyshen, 2018). In Po Plain (Northern Italy) urbanization, agriculture and human activities have greatly reduced the extension of lowland forests to very few remnants (Camerano et al., 2009). Some of these relict forests located in Piedmont region, such as 'Merlino Wood' in Caramagna Piemonte (Maritano, 2020) and 'Bosco delle Sorti della Partecipanza' in Trino (follow called 'Trino Wood') are completely isolated from any other area with arboreal vegetation. This is because they are set into an intensive agriculture landscape, especially corn and hay fields for the first area and rice plantations for the second one. Thanks to this distinctive feature, these natural reserves lend themselves well to study the existing insect assemblages such as hoverflies. Syrphidae can be used as bioindicators (Sommaggio, 1999; Larrieu et al., 2015; Maritano, 2020) of the ecological integrity thanks to the high heterogeneity of the larval ecological preferences in different hoverfly genera. Therefore, in order to standardise the use of Syrphidae as bioindicators the Syrph the Net $(\mathrm{StN})$ database was developed (Speight et al., 2020). This work contributes to the series of investigations (Bertollo et al., 2012; Maritano \& Sommaggio, 2020; Maritano, 2020) aimed at understanding which of the current remnants is closest to the original primary forest that covered Po Plain in the ancient past.

The purposes of this paper are 1) Provide a checklist of the Syrphidae fauna in Trino Wood; and 2) gain a better appreciation of the conservation status of the 2 main woodland habitats in the survey area.

\section{Materials and methods}

\section{Survey area}

Located in North-Western Italy Bosco delle Sorti della Partecipanza is a Regional Natural Park and Site of Community 
Interest (code IT1120002) consisting in a woodland of 586 ha (Figure 1), at 160-200 $\mathrm{m}$ a.s.l.

The main portion is a mesophilic oak-hornbeam that occupies $86 \%$ of the entire wooded area, while the remaining portion is composed by an alder alluvial forest $5,5 \%$ and reforestation $7,1 \%$. The current forest cover consists in Quercus 19\%, Carpinus 35\%, Robinia 19\%. The average age of the oldest Quercus is 115 years with a peak at 145 years, but the regular cut usually takes place at 60-80 years. In the past, negligence or a misguided forest management have led to a wide dissemination of Robinia. In the study area, Robinia appeared for the first time in the XIX century and reached the maximum abundance (39\% of the forest) in 1989 . A simultaneously reduction of the wood volume was recorded in the same year with a value of $79 \mathrm{~m}^{3} / \mathrm{ha}$. The latest management plans encourage a gradual maturity of trees and an improvement of biodiversity also through the mandatory selection of plants with an indefinite senescence in order to obtain a network of old trees. In 2020, the average forest density was 393 specimens of plants (diameter $>7,5 \mathrm{~cm}$ ) per hectare (thirty years ago it was 347 ) and the wood volume increased at $158 \mathrm{~m}^{3} / \mathrm{ha}$. Forestry data come from Guido Blanchard personal comment. Trino Wood is an undivided private property inherited from a group of people that inhabited Trino town in the year 1275 . The common interest and the collective administration were sufficient to protect it from agricultural speculation which caused the transformation of the vast wooded area of the southern Vercelli Province. The few surveys available on the insect fauna are mainly referred to beetles (Allegro et al., 2016), Carabidae coenoses reveal the presence of several regionally isolated species, and the data are supported also by some Orthoptera and Odonata surveys (database of regional managing authorities). No data is available for Diptera, especially Syrphidae.

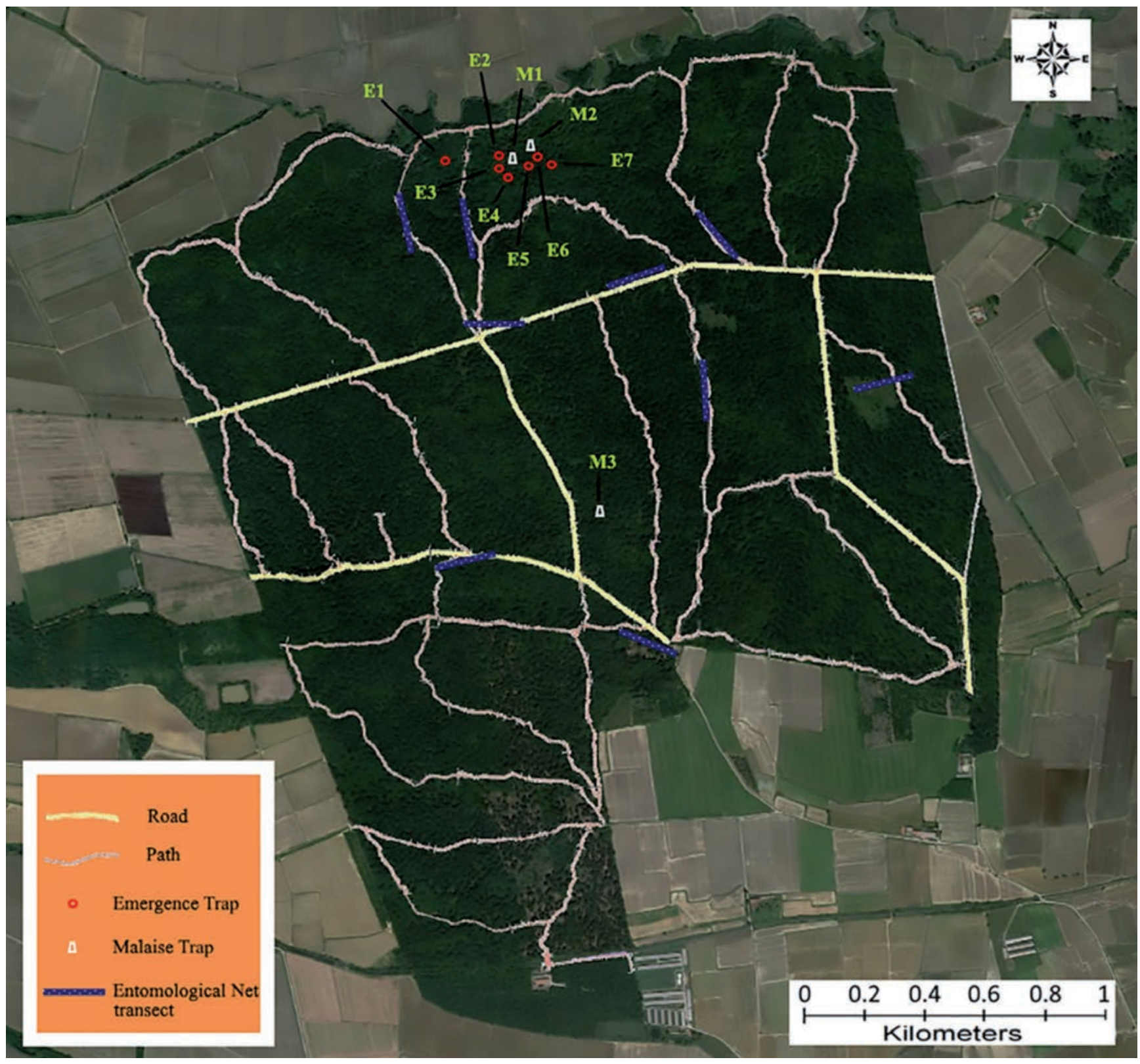

Figure 1. Map of "Bosco delle Sorti della Partecipanza" in Trino (Italy) with setting of traps and transects. 


\section{Monitoring methods}

Field research began on $19^{\text {th }}$ February with the activation of 2 Malaise and 2 Emergence traps and ended on 27th of October with the removal of all traps. Overall, 3 Malaise traps (M1 and M2 in alluvial forest and M3 in oak-hornbeam) and 7 Emergence traps were activated (Figure 1). The locations of the Malaise traps were:

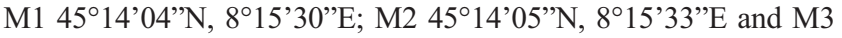
$45^{\circ} 13^{\prime} 26^{\prime} \mathrm{N}, 8^{\circ} 15^{\prime} 41^{\prime \prime} \mathrm{E}$. The distribution of the traps is not proportional to the extent of the two-habitat surveyed due to an unexpected lack of supply. Therefore, it was decided to reduce traps in oak-hornbeam because easier accessible for net transects and simultaneously intensify sight hunts in order to balance monitoring scheme. Malaise traps were set out along small ditches with slow-flowing fresh water and overmature trees. Using an entomological net can be fundamental to increase the performance of samplings (Maritano, 2020; Maritano \& Sommaggio, 2020), for this reason nine $200 \mathrm{~m}$ long transects were defined (Figure 1). Netting was conducted primarily during clear, sunny days with no wind. All netting was carried out between 8:30 and 16:30 with a minimum of 6 hours in each day of sampling activities. Hand harvesting took place every 7 days in April and May and every 10 days during the other months, for a total of more than 120 hours of hand net transects. The specimens collected were partly pinned (reference collection) and partly preserved in $80^{\circ}$ ethyl alcohol. All samples are kept in the author's entomological collection with future deposition in a publicly accessible collection. The keys proposed in Van Veen (2004) and Speight and Sarthou (2017) have been used to identify the species, while the taxonomy follows Burgio et al., (2015).

\section{Syrphids' assets as bioindicators and Syrph the Net analysis}

In Europe Syrphidae fauna count approximately 979 species (Speight et al., 2020), in Italy 536 species (Burgio et al., 2015) and in Piedmont 290 (Maritano unpublished data). At the larval stage, different hoverflies genera, use well separated ecological niches with strict environmental requirements. For this reason, they are considered excellent bioindicators (Speight, 1986; Sommaggio, 1999) and probably the best exhaustive taxon among all insect taxa tested. A central premise of the Syrph the Net (StN) database is that for each macrohabitat, used in the sense of the CORINE European Habitats Classification System, to have its own characteristic assemblage of syrphids, making it possible to predict the potential syrphid fauna of a site from the habitats occurring there (Speight, 2012). The StN database is predictive fuzzy logic expert tool (Keddy, 1992) which can also be used as model that aid in the evaluation of the biodiversity maintenance potential of sites and in the biodiversity management (Speight, 2017). Forest ecosystems are particularly eligible to be assessed by this methodology due to their complexity. The Biodiversity Maintenance Function (BDMF) has been devised as the relationship between species observed in

Table 1. Ranges of BDMF values for each class of assessment according to StN.

\begin{tabular}{lc} 
Range \% & Assessment \\
$0-20$ & Very insufficient \\
$21-40$ & Insufficient \\
\hline $41-50$ & Moderate \\
$51-75$ & Good \\
\hline $76-85$ & Very good \\
$86-100$ & Excellent \\
\hline
\end{tabular}

the field and expected species. BDMF is a numeric parameter expressed as a percentage (Table 1). This ratio can be derived for each macrohabitat or microhabitat (e.g. trunk cavity, herb layer, rotten wood, cow dung etc.) existing in the field, based on the StN database. High BDMF value indicates a well-preserved ecological integrity, by contrast poor ratio denote a scarce conservation condition of one or more microhabitats. The unpredicted species collected, if non migrant, can represent an added value for the site or be indicator of the high complexity in the surrounding landscape (Burgio et al., 2015).

\section{Results}

These sampling have provided a total of 67 species (Table 2). Six species are recorded for the first time in Piedmont. Two species are threatened in Europe and 19 have a decreasing number of population and/or range in Europe (this type of information is in the Excel file: Speight et al., 2020). Furthermore, seven species are threatened in the Continental Biogeographical Region (as defined in Speight \& Castella, 2020) and twenty species are decreasing in the same area (Table 3 ).

As a whole, the study area has a moderately negative ecological integrity as stated by the StN value of $37,50 \%$ (Table 4 ) with alluvial forest well-preserved while the oak-hornbeam section has a poorer preservation. Syrphidae fauna associated with old trees and dead wood seems to be in good conservation conditions. The most under-represented components are the species guilds associated with herb layers.

The use of emergence traps gathers data on the relation between saproxylic species and different substrates (Table 5). This type of relationship is understudied in Italy but can provide interesting suggestions for conservation management actions. In Trino Wood many saproxylophagous species emerged from stump, even if the species of high conservation interest are related to hollows tree.

Hoverflies are fundamental pollinators in several habitats and only recent studies (Chisausky et al., 2020) or projects (LIFE 4 pollinators https://www.life4pollinators.eu/ or Proposal for an EU Monitoring Scheme https://publications.jrc.ec.europa.eu/repository/handle/JRC122225) are investigating their valuable ecosystem service. In Trino Wood several species were observed pollinating flowers (Figure 2). In March Mallota fuciformis can be observed on Prunus. Pyrus supports the quite rare saproxylic species Brachyopa bicolor and Criorhina floccosa. In the study area the greatest hoverflies diversity is seen on Crataegus flowers visited by several genus: Caliprobola, Chalcosyrphus, Chrysotoxum (C. cautum), Ceriana, Dasysyrphus, Didea, Eristalis, Eupeodes, Ferdinandea, Helophilus, Melanogaster, Myatropa, Orthonevra, Parhelophilus, Volucella (V. inflata), Xylota (X. segnis) and scarcely Brachyopa (B. bicolor), Callicera, Myolepta, and Temnostoma (T. bombylans). On Cornus it is possible to see Cheilosia, Meliscaeva, Volucella ( $V$. inflata and $V$. pellucens). The only specimen of Pipiza noctiluca has been reported on Ligustrum. In September, Hedera blooms provide food for various species including Milesia crabroniformis. The many hours spent in the field for the transects, have made possible to draw notes in species consistency. Around half of the recorded species have proved to be scarce $(<5$ specimens observed) or very scarce (only 1 specimen found) in the survey area (Table 2), understood as number of detected specimens during the entire monitoring period. The number of specimens collected by hand net (Table 2) and the number of observed specimens in the field do not always overlap, especially for those species easy to identify in field. 
Table 2. Checklist of Syrphidae sampling in "Bosco della Partecipanza" in Trino. ${ }^{*}$ These species have a scarce consistency in field detected ( $<5$ specimens).

Faunistic list

New record for Piedmont Malaise trap (N of specimens) Net (N) Emergence trap (N)

M1 M2 M3 TOT.

Baccha elongata (Fabricius, 1775)

$1^{*}$

Brachyopa bicolor (Fallén, 1817)

Brachyopa scutellaris Robineau-Desvoidy, 1844

Brachypalpoides lentus (Meigen, 1822)

Brachypalpus valgus (Panzer, 1798)

Caliprobola speciosa (Rossi, 1790)

Callicera fagesii Guérin-Méneville, 1844

Ceriana conopsoides (Linnaeus, 1758)

Chalcosyrphus nemorum (Fabricius, 1805)

Cheilosia scutellata (Fallén, 1817)

Chrysogaster solstitialis (Fallén, 1817)

Chrysotoxum cautum (Harris, 1776)

Chrysotoxum festivum (Linnaeus, 1758)

Criorhina berberina (Fabricius, 1805)

Criorhina floccosa (Meigen, 1822)

Dasysyrphus venustus (Meigen, 1822)

Didea fasciata Macquart, 1834

Epistrophe eligans (Harris, 1780)

Epistrophe nitidicollis (Meigen, 1822)

Episyrphus balteatus (De Geer, 1776)

1844

$3^{*}$

(2)

$\begin{array}{llll}1 & 1 & 1^{*} \\ 2^{*}\end{array}$

$\begin{array}{llll}x & & & \\ & 6 & 4 & 10\end{array}$

1
$1^{*}$
$1^{*}$
1
$3^{*}$
2
$2^{*}$

$\begin{array}{lll}3 & & 3 \\ 3 & & 3 \\ 1 & 5 & 6\end{array}$

Eristalinus sepulchralis (Linnaeus, 1758)

Eristalinus taeniops (Wiedemann, 1818)

Eristalis arbustorum (Linnaeus, 1758)

Eristalis interrupta (Poda, 1761)

Eristalis pertinax (Scopoli, 1763)

$\begin{array}{lll}5 & 6 & 1 \\ 2 *\end{array}$

Eristalis similis (Fallén, 1817)

Eristalis tenax (Linnaeus, 1758)

Eumerus flavitarsis Zetterstedt, 1843

Eumerus ornatus Meigen, 1822

Eupeodes corollae (Fabricius, 1794)

Eupeodes latifasciatus (Macquart, 1829)

Ferdinandea cuprea (Scopoli, 1763)

Ferdinandea ruficornis (Fabricius, 1775)

Helophilus pendulus (Linnaeus, 1758)

Helophilus trivittatus (Fabricius, 1805)

Mallota fuciformis (Fabricius, 1794)

Melanogaster aerosa (Loew, 1843)

Melanostoma mellinum (Linnaeus, 1758)

Meliscaeva auricollis (Meigen, 1822)

Mesembrius peregrinus (Loew, 1846)

Milesia crabroniformis (Fabricius, 1775)

Myathropa florea (Linnaeus, 1758)

Myolepta obscura (Becher, 1882)

Neoascia meticulosa (Scopoli, 1763)

Neoascia podagrica (Fabricius, 1775)

Neoascia tenur (Harris, 1780)

Orthonevra brevicornis (Loew, 1843)

Paragus haemorrhous Meigen, 1822

\begin{tabular}{lllll} 
& & & & \\
& 17 & & 17 \\
3 & 2 & 1 & 6 \\
\hline
\end{tabular}

2
1

$1^{*}$

*

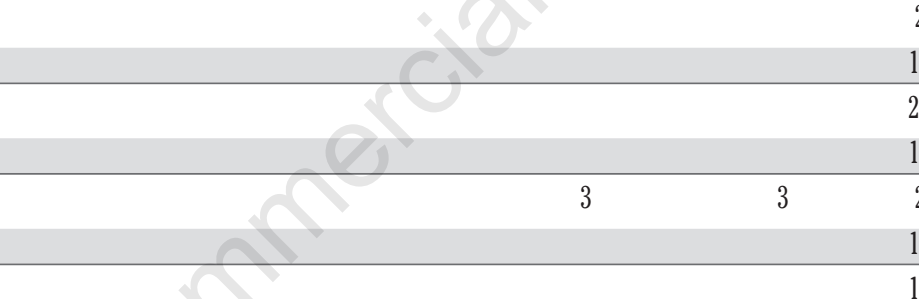

$(1)+1$

\begin{tabular}{|c|c|c|c|c|}
\hline+8 & & 1 & & 1 \\
\hline 3 & & & 1 & 1 \\
\hline & 3 & & 1 & 4 \\
\hline & 14 & 12 & 1 & 27 \\
\hline
\end{tabular}

$\begin{array}{llll}x & 1 & 1 & 2 \\ & 1 & 1 & 2\end{array}$

$\begin{array}{lll} & x & 3^{*} \\ 75) & 1^{*}\end{array}$

$\begin{array}{lllll}x & 1 & 1 & 1 \\ x & & & 1 \\ & & 1\end{array}$

$1^{*}$

\section{$1 *$}

\section{3} 5 * $1^{*}$

$1 *$

$1 *$

$\begin{array}{rrrr}6 & 7 & 13 & 2 \\ & \end{array}$

To be continued on next page 
Table 1. Continued from previous page.

$\begin{array}{lll}\text { Faunistic list } & \text { New record for Piedmont } & \text { Malaise trap (N of specimens) } \\ & \text { Net (N) Bmergence trap (N) }\end{array}$

Paragus pecchiolii Rondani, 1857

1 *

Parhelophilus frutetorum (Fabricius, 1775)

Pipiza noctiluca (Linnaeus, 1758)

Scaeva pyrastri (Linnaeus, 1758)

Sphaerophoria rueppelli (Wiedemann, 1830)

Sphaerophoria scripta (Linnaeus, 1758)

Syritta pipiens (Linnaeus, 1758)

Syrphus ribesii (Linnaeus, 1758)

Syrphus vitripennis Meigen, 1822

Temnostoma bombylans (Fabricius, 1805)

Temnostoma vespiforme (Linnaeus, 1758)

Volucella inanis (Linnaeus, 1758)

Volucella inflata (Fabricius, 1794)

Volucella pellucens (Linnaeus, 1758)

Volucella zonaria (Poda, 1761)

Xanthandrus comtus (Harris, 1780)

Xanthogramma stackelbergi Violovitsh, 1975

Xylota segnis (Linnaeus, 1758)

Xylota sylvarum (Linnaeus, 1758)

$\begin{array}{ccccc} & 2 & 1 & 3 & 1^{*} \\ \mathrm{x} & 3 & 1 & 4 & 1\end{array}$

$1^{*}$

)




\section{Discussion}

The total number of 67 species found in the study area can be considered similar to the other faunistic studies available (Birtele et al. 2002; Maritano, 2020) for the same type of habitat. This monitoring can be considered as exhaustive because the use of both Malaise traps and Entomological Net transects are expected to be complementary in the collection of adult hoverflies (Burgio \& Sommaggio, 2002), although it may need intensification of Malaise traps for oak-hornbeam portion. In forest ecosystems, well-organised netting samplings can greatly increase the number of species captured compared to using only passive methods (Maritano \& Sommaggio, 2020; Maritano, 2020). The use of emergence traps has been designed for the purpose of collecting exceedingly rare saproxylic species, and even if the results obtained (Table 5) are not fully satisfactory, the data may suggest that the partially alive trees and/or the dis- tance from fresh water might be fundamental factors that affect larvae development.

According to the StN analysis, at the forest ecosystem level, the ecological integrity is moderately negative, but alluvial alder forest has a better conservation status compared to the oak one. Alluvial forest is particularly rich in species as stated by the StN value and many of them are sampled only a few times in Po Plain such as Chrysogaster solstitialis, Melanogaster aerosa, Mesembrius peregrinus and Neoascia meticulosa. The last three species are recorded for the first in Piedmont region. Overall, in Trino wood saproxylic species are well represented with a StN value of $60 \%$ and many of them are of remarkable conservation interest. Only recently, Temnostoma genus has been recorded for the first time in Piedmont region (Maritano \& Sommaggio., 2020). The simultaneous presence of both Italian species in the same locality is very infrequent South of the Alps (Whitmore et al., 2008; this work) and can suggest a well-preserved alluvial forest remnant. Callicera fagesii has a wide distribution in Italy (Burgio

Table 3. Species of hoverflies collected in Trino Wood or expected but not observed, with the threat level degree according to Speight \& Castella (2020) in the last StN version. C.B.R.: Continental Biogeographical Region. Unpredicted: species observed but not predicted for the two main habitats. Value: from 1 moderate threat to 3 high threat.

\begin{tabular}{|c|c|c|c|c|c|c|c|}
\hline \multirow[t]{3}{*}{ Species observed } & \multirow{2}{*}{\multicolumn{3}{|c|}{ Expected habitat (StN database) }} & \multicolumn{4}{|c|}{ Threath level degree } \\
\hline & & & & \multicolumn{2}{|c|}{ Europe } & \multicolumn{2}{|c|}{ C. B. R. } \\
\hline & Oak-hornbeam & Alnus & Unpredicted & $\mathrm{T}$ & D & $\mathrm{T}$ & D \\
\hline Brachyopa bicolor & $\mathrm{x}$ & $\mathrm{x}$ & & & 1 & & 2 \\
\hline Brachyopa scutellaris & $\mathrm{x}$ & $\mathrm{x}$ & 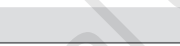 & & & & 1 \\
\hline Brachypalpus valgus & $\mathrm{x}$ & $\mathrm{x}$ & 7 & & 2 & 1 & 2 \\
\hline Caliprobola speciosa & & & $\mathrm{x}$ & & 3 & & 3 \\
\hline Callicera fagesii & & & $\mathrm{x}$ & & 3 & 1 & 2 \\
\hline Ceriana conopsoides & $\mathrm{x}$ & & & & 3 & & 3 \\
\hline Chrysotoxum cautum & $\mathrm{x}$ & 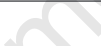 & & & 1 & & 1 \\
\hline Criorhina floccosa & $\mathrm{x}$ & $\mathrm{x}$ & & & 1 & & 3 \\
\hline Ferdinandea ruficornis & $\mathrm{x}$ & & & 1 & 2 & 2 & 1 \\
\hline Mallota fuciformis & $\mathrm{x}$ & & & 2 & 2 & 2 & 2 \\
\hline Melanogaster aerosa & ( & & $\mathrm{x}$ & & 2 & 1 & 2 \\
\hline Mesembrius peregrinus & 8 & & $\mathrm{X}$ & & 2 & 2 & 1 \\
\hline Milesia crabroniformis & $\mathrm{x}$ & & & & 2 & & 2 \\
\hline Myolepta obscura & $\mathrm{x}$ & & & & 2 & 3 & \\
\hline Neoascia meticulosa & & & $\mathrm{x}$ & & & & 2 \\
\hline Orthoneura brevicornis & & $\mathrm{x}$ & & & 2 & & 2 \\
\hline Parhelophilus frutetorum & & $\mathrm{x}$ & & & 1 & & 2 \\
\hline Temnostoma bombylans & $\mathrm{x}$ & $\mathrm{x}$ & & & 1 & & 3 \\
\hline Temnostoma vespiforme & $\mathrm{x}$ & $\mathrm{x}$ & & & 1 & & 3 \\
\hline Volucella inflata & $\mathrm{x}$ & $\mathrm{x}$ & & & 1 & & 2 \\
\hline Xanthogramma stackelbergi & & & $\mathrm{x}$ & & 2 & & 2 \\
\hline & Expecte & ecies n & served & & & & \\
\hline Chalcosyrphus valgus & $\mathrm{x}$ & & & & 2 & & \\
\hline Chrysotoxum octomaculatum & $\mathrm{x}$ & & & & 1 & & \\
\hline Chrysotoxum verralli & $\mathrm{x}$ & & & & 1 & & \\
\hline Microdon mutabilis & $\mathrm{x}$ & & & 2 & 2 & & \\
\hline Merodon constans & $\mathrm{x}$ & & & & 3 & & \\
\hline Pocota personata & $\mathrm{x}$ & & & & 2 & & \\
\hline Psarus abdominalis & $\mathrm{x}$ & & & 3 & & & \\
\hline Psilota anthracina & $\mathrm{x}$ & & & & 2 & & \\
\hline Rhingia rostrata & $\mathrm{x}$ & & & 1 & 2 & & \\
\hline
\end{tabular}


et al., 2015) although it has been recorded in very few localities (Birtele et al., 2002), this species is strongly associated with overmature forests and it is rare due to strict environmental requirements. Another remarkable species found in Trino wood is Myolepta obscura. This is an extremely rare saproxilic hoverfly in Europe (Speight, 1989; Ricarte et al., 2007) and appears scarce all over its distribution (Reemer et al., 2005; Sommaggio, 2017; Delsinne, 2020; Van Steenis, 2020). It has been reported for the first time in Italy by Reemer et al. (2005) near the border with Slovenia and it has been recently collected in North-Eastern Po Plain (Sommaggio, 2017). M. obscura occurs in well-developed deciduous woodlands, including alluvial forests (Reemer et al., 2005), larvae develop in wet holes of tree trunks of Fraxinus angustifolia (Ricarte et al., 2007) or senescent Populus or Quercus/Carpinus/Ulmus forests (Speight, 2020). Since no adults were collected by the emergence traps and the only specimen found in this survey comes from a Net transect located in an ecotone between alluvial forest and Quercus mesophilic vegetation, it is impossible to state which type of arboreal vegetation supports this species in Trino wood. Many saproxylophagous species, usually of high conservation interest, were observed only in the ecotone between alluvial forest and Quercus mesophilus vegetation, such us: Mallota fuciformis, Ceriana conopsoides, Myolepta obscura, Brachyopa spp. and Callicera fagesii. Since many of them have larvae linked to overmature Quercus (Speight, 2020) this element may suggest a better Habitat quality near the humid area in opposite to the main managed forest. However, some saproxylic species seem to have a more widely distribution in the study area, because they are seen or collected in different Net transects or traps, namely: Ferdinandea ruficornis, Milesia crabroniformis, Caliprobola speciosa and Brachypalpus valgus.

In the study area several unpredicted non-migrant species

Table 4. Derivation of BDMF for each Macrohabitat and Microhabitat, based on Syrph the Net.

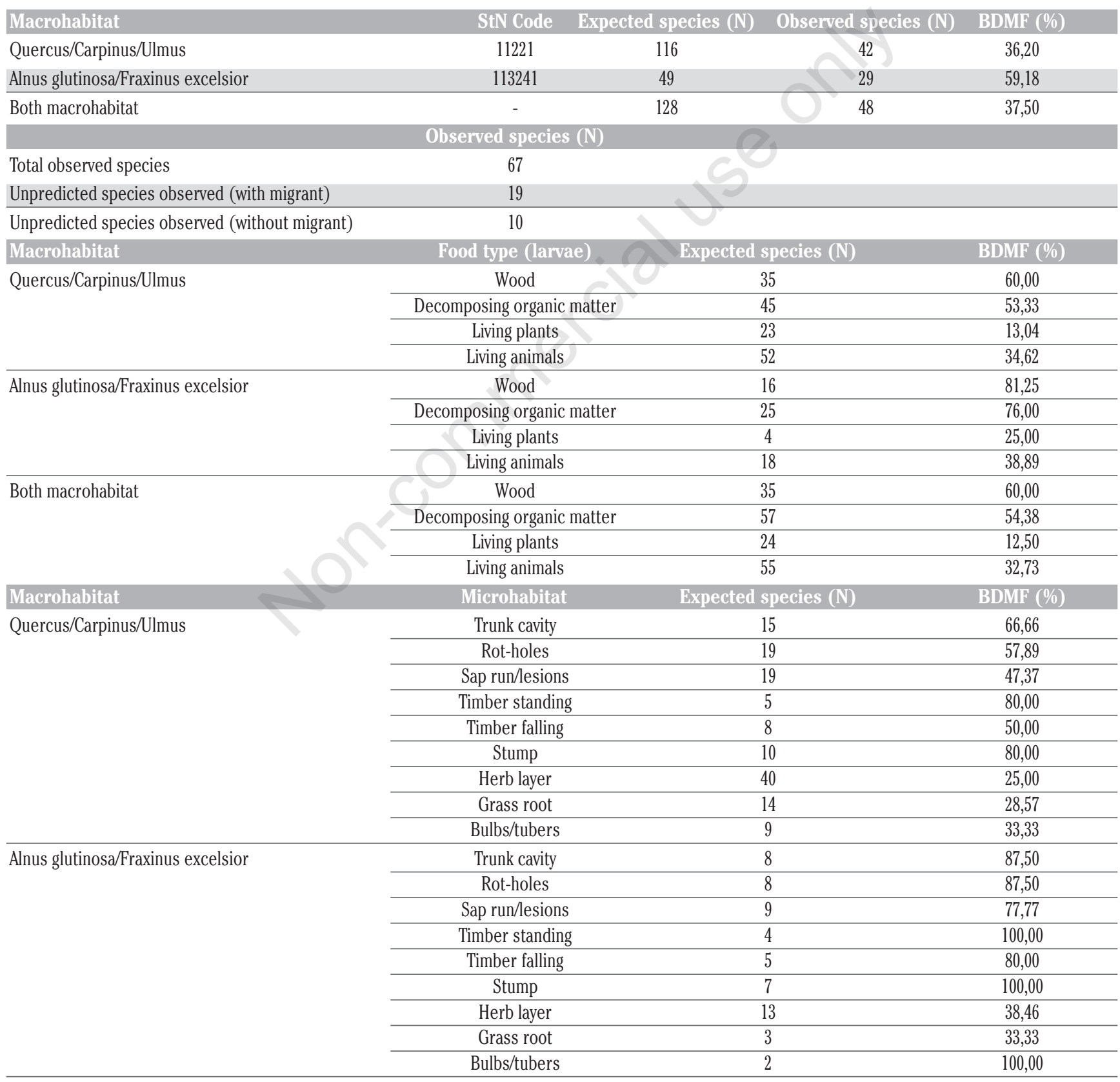


Table 5. Emergence traps in Trino Wood.

\begin{tabular}{|c|c|c|c|c|}
\hline Trap & Activity period & Tree & Substrate & Species (Number of specimens collect) \\
\hline E1 & 28 February -27 October & Alnus glutinosa & Stump, tree alive, near water $(<3 \mathrm{~m})$ & $\begin{array}{c}\text { Myatropa florea (3), Chalcosyrphus nemorum (1), } \\
\text { Xylota sylvarum (1) }\end{array}$ \\
\hline E2 & 28 February -27 October & - & $\begin{array}{l}\text { Stump, dead tree from several years, } \\
\text { along water }(>20 \mathrm{~m})\end{array}$ & - \\
\hline E3 & 23 April - 27 October & Quercus & Hollows tree at $1 \mathrm{~m}$ from soil, tree alive & Criorhina floccosa (1) \\
\hline E4 & 28 February - 27 October & Probably Alnus & $\begin{array}{c}\text { Stump, dead tree from few years }(<3) \text {, } \\
\text { near water }(<3 \mathrm{~m})\end{array}$ & $\begin{array}{l}\text { Criorhina berberina (2), } \\
\text { Chalcosyrphus nemorum (1) }\end{array}$ \\
\hline E5 & 06 May -27 October & Quercus & Hollows tree near soil, tree alive & Caliprobola speciosa (1) \\
\hline E6 & 06 May -27 October & Fraxinus & Hollows tree, full water, at $40 \mathrm{~cm}$ from soil, tree alive & Myatropa florea (1) \\
\hline E7 & 17 May - 27 October & Carpinus betulus & Hollows tree, full water, near soil, tree alive & \\
\hline
\end{tabular}

have been collected, namely: Caliprobola speciosa, Callicera fagesii, Eristalinus sephulcralis, Eumerus flavitarsis, Melanogaster aerosa, Mesembrius peregrinus, Neoascia meticulosa, Neoascia tenur, Paragus haemorrhous and Xanthogramma stackelbergi. According to the $\mathrm{StN}$ database C. speciosa, E. flavitarsis and $X$. stackelbergi can be associated with thermophilus Quercus. In Trino Wood there is a litle hill (located in SouthWestern portion) that is sunny and dry in summer with shrubbery of Ruscus aculeatus, but it cannot be considered a fully thermophilus Quercus Habitat. According to StN (Speight, 2012) the unpredicted non-migrant species may be a factor of uniqueness of the area and therefore they may represent an added value to the site biodiversity.

\section{Conclusions}

The ecological integrity of Bosco delle Sorti della Partecipanza is moderately negative, probably because of the past massive wood harvests that must have affected biodiversity in the main oak-hornbeam forest. Nevertheless, saproxylic species are well-represented and count several rare species and aquatic saprophagous species make the alluvial forest of conservation interest. A dramatically low value of BDMF, referred to phytophagous species (with similar rates in root and herb layers), has been known also in Merlino Wood (Maritano, 2020). Since the forest has never been pastured, it is difficult to explain the causes of this deficiency, perhaps soil compaction by logging or the paucity of natural clearings can be a contributing factor. However, the presence of a high number of threatened or decreasing species at European level makes the study area an important source of biodiversity at least at the regional scale. Further studies of this diverse group of pollinators may be required to better understand the species distribution through the forest and the amount of substrate suitable for their larval development, especially for high conservation interest genera such as Callicera, Mallota and Myolepta. This potential research would have to consider the implementation of measures of retention ecology or restoration ecology, applied especially to tree hollows, as a tool to promote the conservation of target species.

\section{References}

Allegro G., CASAle A., CHIARABAGlio P.M., DElla BEFFA G., 2016 - I Carabidi del Bosco delle Sorti della
Partecipanza di Trino (Coleoptera, Carabidae) (Italia, Piemonte). - Riv. Piemont. Storia Nat. 37: 189-209.

BERTOLLO S., CORAZZA C., SOMMAGGIO D., 2012 - La valutazione della biodiversità in 12 siti della provincia di Ferrara. - In: Ferrara MCdSNd (Ed.) I Ditteri Sirfidi nella bioindicazione della biodiversità. 20. Ferrara, 169 pp. URL: https://storianaturale.comune.fe.it/modules/ core/lib/d.php?c=cDJP2

BIRTELE D., SOMMAGGIO D., SPEIGHT M.C.D., TISATO M., 2002 - Syrphidae, pp. 115-118. In: Invertebrati di una foresta della Pianura Padana Bosco della Fontana, Conservazione habitat invertebrati 1 (MASON F., CERRETTI P., TAGLIAPIETRA A., SPEIGHT M. C. D., ZAPPAROLI A., Eds) - Arcari Editore, Mantova, Italy.

BURGIO G., SOMMAGGIO D., 2002 - Diptera Syrphidae caught by Malaise trap in Bologna province and new record of Neoascia interrupta in Italy. - Bull. Insectol. 55: 43-47.

BURGIO G., SOMMAGGIO D., BIRTELE D., 2015 - I sirfidi (Ditteri): biodiversità e conservazione. - ISPRA, Manuali e Linee Guida 128/2015.

CAMERANO P., TERZUOLO P.G., SINISCALCO C., 2009 - I boschi planiziali del Piemonte. - Natura Bresciana annali del Museo civico di Storia naturale, Brescia, 36: 185-189.

CHISAUSKY JL., SOLEY NM., KASSIM L., BRYAN CJ., MIRANDA GFG., GAGE KL., SIPES SD., 2020 - Syrphidae of Souther Illinois: Diversity, floral associations, and preliminary assessment of their efficacy as pollinators. - Biodiv. Data J. 8: e57331.

DELSINNE T., 2020 - Nouvelles données concernant le genre Myolepta en Auvergne-Rhône-Alpes. - Arvernsis 89-90: 1-7

KEDDY P.A., 1992 - Assembly and response rules: two goals for predictive community ecology. - J. Veg. Sci. 3: 157-164.

LARRIEU L., CABANETTES A., SARTHOU J.P., 2015 Hoverfly (Diptera: Syrphidae) richness and abundance vary with forest stand heterogeneity: Preliminary evidence from a montane beech fir forest. . Eur. J. Entomol. 112: 755-769.

MARITANO U., 2020 - Hoverfly (Diptera: Syrphidae) assemblage of an oak-hornbeam in the Merlino Wood Natural Reserve and implications for its conservation. - Biodiv. Data J. 8: 54243.

MARITANO U., SOMMAGGIO D., 2020 - Hoverfly diversity in Mareschi alluvial alder forest (Piedmont, Italy), and "Syrph the Net" ecological analysis (Diptera: Syrphidae) - Fragmenta Entomol. 52: 101-112.

REEMER M., HAUSER M., SPEIGHT M.C.D., 2005 - The genus Myolepta Newman in the West-Palaearctic region (Diptera, Syrphidae) - Studia Dipterol. 11: 553-580.

RICARTE A., MARCOS-GARCIA M.A., PEREZ-BANON C., 
ROTHERAY G.E., 2007 - The early stages and breeding sites of four rare saproxylic hoverflies (Diptera: Syrphidae) from Spain - J. Nat. Hist. 41: 1717-1730.

SOMMAGGIO D., 1999 - Syrphidae: can they be used as environmental bioindicators? - Invertebrate Biodiversity as Bioindicators of Sustainable Landscapes 343-356.

SOMMAGGIO D., 2017 - The hoverfly fauna of the Berici Hills: an area of rich biodiversity in north-estern Italy. -Bull. Insectol. 70: 101-110.

SPEIGHT M.C.D., 1986 - Criteria for the selection of insects to be used as bioindicators in nature conservation research, - Proc. 3rd Eur. Cong. Ent. Amsterdam, n³, p485-488.

SPEIGHT M.C.D., 1989 - Saproxylic invertebrates and their conservation. - Council of Europe, Strasbourg, 79 pp.

SPEIGHT MCD., 2012 - The Syrph the Net of European Syrphidae (Diptera). In: Speight MC (Ed.) I Ditteri Sirfidi nella bioindicazione della biodiversità. 20. - Museo civico di Storia naturale di Ferrara, Ferrara, 23-44 pp.

SPEIGHT M.C.D., 2017 - The Syrph the Net database of European Syrphidae (Diptera), past, present and future. - Syrph the Net, the database of European Syrphidae (Diptera), Vol. 96, 19 pp., Syrph the Net publications, Dublin.

SPEIGHT M.C.D., 2020 - Species accounts of European Syrphidae, 2020. - Syrph the Net, the database of European Syrphidae (Diptera), vol. 104, 314 pp., Syrph the Net publications, Dublin.

SPEIGHT M.C.D., CASTELLA E., 2020 - StN Database: Content and Glossary of terms, 2020. - Syrph the Net, the database of
European Syrphidae (Diptera), Vol. 107, 98 pp, Syrph the Net publications, Dublin.

SPEIGHT M.C.D., SARTHOU J.P., 2017 - StN keys for the identification of the European species of various genera of Syrphidae 2017 - Syrph the Net, the database of European Syrphidae (Diptera), Vol. 99, 139 pp, Syrph the Net publications, Dublin.

SPEIGHT M.C.D., CASTELLA E., SARTHOU J.P., 2020 - StN 2020. - In: Syrph the Net on CD, Issue 12. Speight, M.C.D., Castella, E., Sarthou, J.-P. \& Vanappelghem, C. (Eds.) ISSN 1649-1917. Syrph the Net Publications, Dublin.

ULYSHEN MD., 2018 - Saproxylic Insects. - Zoological Monographs 1.

VAN STEENIS J., 2020 - A new species of the genus Myolepta Newman (Diptera: Syrphidae), with short description and key to all species of the M. vara subgroup. - Zootaxa 4750: 370-390.

VAN VEEN M.P., 2004. Hoverflies of Northwest Europe. KNNV Publishing, Zeist, The Netherlands, 247 p.

WHITMORE D., BIRTELE D., MASON F., 2008 - Stratiomyidae, Syrphidae and Sarcophagidae (Diptera: Brachycera) from the understorey and canopy of a riparian forest ecosystem in Italy, pp. 239-251. In: Hardersen S., Mason F., Viola F., Campedel D., Lasen C. \& Cassol M. (eds), Research on the natural heritage of the reserves Vincheto di Celarda and Val Tovanella (Belluno province, Italy). Conservation of two protected areas in the context of a LIFE Project. - Quaderni Conservazione Habitat, 5. Arti Grafiche Fiorini, Verona. 